\title{
코로나바이러스감염증- $19(\mathrm{SARS}-\mathrm{CoV}-2$ 감염증)의 임상 양상과 치료
}

부산대학교 의과대학 내과학교실 감염내과 및 부산대학교병원 의학연구소

이신원

\section{Clinical Features and Treatment of Coronavirus Disease-19 (Severe Acute Respiratory Syndrome Coronavirus 2 [SARS-CoV-2] Infection)}

\author{
Shinwon Lee, MD, PhD \\ Department of Internal Medicine, Pusan National University School of Medicine and Medical Research Institute, \\ Pusan National University Hospital, Busan, Korea
}

\begin{abstract}
- ABSTRACT -
The coronavirus disease 2019 (COVID-19) pandemic, due to the novel severe acute respiratory syndrome coronavirus 2 (SARS-CoV-2), has lasted for over 10 months. During the pandemic, clinical experience of COVID-19 has been accumulated and numerous researches have performed for better understanding of COVID-19. This review provides current evidence regarding transmission, clinical manifestation and management of COVID-19. SARS-CoV-2 is mainly spread through respiratory transmission during close contact and presymptomatic transmission is a major contributor to the spread of SARS-CoV-2. Many studies demonstrated that wearing a mask, both in health care settings and in the community, can markedly reduce transmission of SARS-CoV-2. Clinical manifestations, laboratory findings and imaging findings of COVID-19 are usually overlap with other infections. Approximately one fifth of patients with COVID-19 experience severe manifestation and 5\% of patients need intensive care. Respiratory supportive care is one of most important treatment for COVID-19, because necessitating intensive care of patients with COVID-19 is usually due to hypoxemic respiratory failure. So far, two drugs were proved significant therapeutic effects; remdesivir improves time to recovery from 15 to 11 days and dexamethasone reduces 28-day mortality in patients requiring supplemental oxygen compared with usual care. Until an effective therapeutics and vaccines are available, masks and social distancing are the best ways to minimize the risk of transmission of COVID-19. (J Clinical Otolaryngol 2020;31:155-163)
\end{abstract}

KEY WORDS: COVID-19 - SARS-CoV-2 $\cdot$ Coronavirus $\cdot$ Transmission $\cdot$ Treatment.

\section{서 론}

2019년 12월부터 중국 후베이성 우한시에서는 다수 의 원인미상 폐렴 환자가 발생하였다. 2020년 1월 7일, 중국 질병예방통제센터는 이 폐렴 환자들이 이전에 알
려지지 않은 새로운 코로나바이러스에 감염되었음을 공 개하였다. ${ }^{1)}$ 세계보건기구(World Health Organization, $\mathrm{WHO}$ )는 이 새로운 코로나바이러스 감염증을 coronavirus disease 2019(COVID-19)로 명명하였다.

COVID-19는 채 3 개월이 되기도 전에 약 114 개

논문접수일: 2020년 10월 31일 / 논문수정일: 2020년 11월 18일 / 심사완료일: 2020년 11월 25일

교신저자: 이신원, 49241 부산광역시 서구 구덕로 179 , 부산대학교 의과대학 내과학교실 감염내과 및 부산대학교병원 의학연구소

전화: (051) 240-7674 ·전송: (051) 247-3213·E-mail: ebenezere.lee@gmail.com 
국으로 확산되었으며, $\mathrm{WHO}$ 는 2020년 3월 11일에 COVID-19가 세계적 대유행(pandemic) 상황이라고 선 언하였다. ${ }^{2)}$ 확산을 막고자 하는 여러 노력에도 불구하 고 대유행의 규모는 더욱 확산되었고, 2020년 10월 현 재 전세계 200개국 이상에서 4천 4백만명 이상이 감염 되고, 백십만명 이상이 COVID-19로 인해 사망하였 다. ${ }^{3)}$ 최근에는 유럽과 미국을 중심으로 COVID-19의 재확산세가 뚜렷하고, 다가오는 인플루엔자 시즌과 겹 쳐져 두 가지 감염증의 동시 유행(twindemic) 가능성에 대한 우려도 커지고 있다.

우리나라에서도 2020년 1월 20일에 첫 환자가 보고 된 이후, 2020년 10월까지 누적 확진자가 26,000명 발 생하였고, 462명이 사망하였다. ${ }^{4}$ 국내에서는 대유행 초 기 대구, 경북을 중심으로 대규모 집단발생이 있은 이 후, 환자가 급증하고 있지는 않으나 전국적으로 환자 발 생이 보고되고 있으며, 특히 감염 경로 불명환자의 비율 이 증가하고 있는 추세이다.

유행이 지속되면서 COVID-19에 대한 임상 경험이 축적되었고, 감염 전파, 임상 경과 치료 방법에 대한 연 구들이 지속적으로 발표되었다. 따라서, 이번 종설에서 는 2020년 10월 29일 현재까지 알려진 COVID-19의 감 염 전파 양상의 특징과 임상적 특성, 현재까지 효과가 입증된 치료법에 대해 고찰해 보고자 한다.

\section{본 론}

\section{바이러스 명칭}

코로나바이러스는 외피에 싸여 있는 단일 가닥(single-stranded) RNA 바이러스로 외피에 $20 \mathrm{~nm}$ 의 왕관 모양과 같은 돌기(spikes)가 있어 전자현미경 사진에서 태양의 코로나(corona)처럼 보이기 때문에 코로나바이 러스로 명명되었다. 코로나바이러스는 1960년대에 인 체의 호흡기에서 처음 분리되어 배양되었는데, 현재까 지 인체에 병원성을 가지는 것으로 알려진 것은 $229 \mathrm{E}$, NL63, OC43, HKU1, SARS-CoV, MERS-CoV 이렇 게 6종이다. 그중 SARS-CoV와 MERS-CoV를 제외 한 229E, NL63, OC43, HKU1는 병독성이 약한 바이러 스로 경증 상기도 감염인 감기(common cold)의 원인이 되는 바이러스이다.
2019년 12월 중국 우한에서 발생한 원인불명 중 증 폐렴의 원인이 새로운 코로나바이러스임이 밝혀 진 이후 이 코로나 바이러스는 2019 novel coronavirus (2019-nCoV)로 잠정적으로 불렸다. 계통발생학 적 (phylogenetic) 분석연구에서 이 새로운 코로나바 이러스의 염기 서열이 SARS-CoV와 MERS-CoV의 염기서열과 각각 $79.0 \%, 51.8 \%$ 일치하였으며, 박쥐의 SARS-like coronavirus (bat-SL-CoVZC45)와는 약 87.6 89\% 일치하여 가장 유사하였다. ${ }^{5,6)}$ International Committee on Taxonomy of Viruses의 코로나바이러 스 연구회(Coronaviridae Study Group)는 계통발생학 적(phylogenetic) 분석 결과에 따라 이 새로운 바이러 스를 severe acute respiratory syndrome-associated coronavirus 2(SARS-CoV-2)로 명명하였다. ${ }^{7)}$ 이어서 $\mathrm{WHO}$ 는 SARS-CoV-2에 감염되어 발생하는 질환을 2019년 새로 발견된 코로나바이러스에 의한 질환을 뜻 하는 coronavirus disease 2019(COVID-19)으로 명명 하였다.

\section{바이러스 전파}

첫번째로 가능한 SARS-CoV-2의 감염 전파 방식은 대화나 기침 또는 재채기를 할 때 발생하는 비말을 통 한 비말 전파 방식이다. 이러한 면대면 (face-to-face) 밀접 접촉을 통한 비말 전파가 SARS-CoV-2 감염 전 파 방식 중 가장 중요한 감염전파방식이라고 할 수 있으 며, 가까운 거리에서 상당한 시간 동안 감염자에 노출이 있었거나(2미터 이내에서 15 분 이상), 기침 등의 증상이 있는 감염자에 노출이 있었을 때 감염 전파의 위험이 더 높다. ${ }^{8)}$

COVID-19 환자는 대개 증상 발생 2 3일 전부터 상 기도에서 SARS-CoV-2는 바이러스 배출이 시작되 고, 증상 발생 시점에서는 바이러스 배출이 최대에 이른 다. ${ }^{9)}$ 그러나 SARS-CoV-2 감염자는 감염 첫 주에 상 기도를 통해 다량의 바이러스를 배출하여 여러 사람에 게 감염 전파가 가능함에도 불구하고, 증상을 느끼지 못 하거나, 일상생활에 지장이 없을 정도로 증상이 경미해 서 감염자가 SARS-CoV-2 감염 사실을 인지하지 못 하는 경우가 많다. ${ }^{10)}$ 실제로 Ganyani T 등은 역학 연구 분석에서 COVID-19 감염전파의 $48 \%$ 62\%가 증상 발 
생 전 또는 무증상인 상태에서 발생한 것으로 분석하였 다. ${ }^{11)}$ 이러한 SARS-CoV-2의 바이러스 배출 특성 때 문에 감염을 관리하고 통제하는 것이 매우 어렵다. 감 염자가 감염사실을 인지하지 못한 상태에서 일상활동을 지속하는 동안에도 많은 양의 바이러스를 배출하여 다 수의 접촉자에게 감염전파를 시킬 수 있기 때문이다. ${ }^{10)}$

그렇다면, 감염자가 얼마나 오랜 기간 동안 다른 사 람들에게 감염전파가 가능할까? 증상 발생 후 6주가 경 과한 시점에서도 감염자의 호흡기 검체에서 SARS$\mathrm{CoV}-2$ 바이러스의 핵산은 검출되는 것으로 보고되었 다. ${ }^{2)}$ 그러나, 바이러스의 핵산이 지속적으로 검출되는 것이 감염 전파력이 지속됨을 의미하지는 않는다. 감염 전파의 가능성을 간접적으로 확인하는 지표로 바이러스 배양 검사 결과가 중요한데, 증상 발생후 8일 이상 경과 하면 호흡기 검체에서 SARS-CoV-2 바이러스의 핵산 이 검출되더라도 바이러스 배양은 되지 않았다. ${ }^{9)}$ 대만 에서 시행된 접촉자 추적 역학 연구에서도 감염자가 증 상이 시작되고 5 일 이상 경과한 시점에서 감염자와 접 촉한 경우 감염전파가 발생하지 않았다. ${ }^{13)}$ 따라서, 증상 발생 후 10 일이 경과하면 감염전파의 가능성이 현저하 게 낮아진다고 할 수 있다. $\mathrm{WHO}$ 는 이러한 결과를 바탕 으로 증상 발생후 10 일이 경과한 이후 3일을 더 관찰하 여 발열이나 호흡기 증상이 없으면 격리를 해제할 수 있 다고 권고하고 있다. ${ }^{14)}$

그러나, 면역저하자가 인플루엔자와 같은 다른 호흡 기 바이러스에 감염되면 정상 면역인 경우에 비해 감 염 가능한 바이러스를 더 오랜 기간 배출하는 것처럼, ${ }^{15)}$ SARS-CoV-2도 면역 저하자에서는 바이러스 배출 이 상당기간 지속될 수 있다. 실제로, 장기 이식을 받은 환자들을 대상으로 한 연구에서 면역저하자가 SAR$\mathrm{CoV}-2$ 바이러스 배출이 더 오랜 기간 지속됨을 보고하 였다. ${ }^{16,17)}$ 또한 COVID-19의 중증도에 따라서도 바이 러스 배출 기간이 달라질 수 있는데, 최근 네덜란드에서 발표된 연구에 따르면, 중증 환자에서는 증상 발생 후 20 일 뒤까지 감염력이 있는 바이러스의 배출이 있는 것 으로 보고하였다. ${ }^{18)}$ 따라서, 경증환자의 경우, $\mathrm{WHO}$ 의 기준에 따라 격리해제를 할 수 있으나, 면역저하자나 중 증 경과를 보였던 환자의 경우 별도의 격리해제 기준이 필요하다. 이러한 경우, 국내 지침에서는 의사의 판단
에 따라 격리해제를 할 수 있도록 하였고, 핵산 검사 결 과의 음성 전환 여부가 감염 가능성의 해소 여부와 일치 하지 않는 문제점에도 불구하고, 기존의 핵산 검출 검사 결과를 기준으로 음성을 확인하는 격리해제 지침을 적 용하고 있다. ${ }^{19}$

$\mathrm{SARS}-\mathrm{CoV}-2$ 는 공기를 통해서도 감염 전파가 가능 할까? COVID-19 환자가 사용한 병실에서 감염 전파가 가능한 바이러스가 존재하는 것이 확인되었다. ${ }^{20,21)}$ 공기 중에 바이러스가 존재하는 것으로 공기를 통한 감염 전 파가 입증되었다고 할 수 없으나, 에어로졸이 대량으로 생성되는 환경에서는 에어로졸을 통한 공기 전파로도 COVID-19의 감염 전파가 가능할 것으로 생각된다.

비말 전파나 에어로졸을 통한 공기 전파가 COVID19 의 주된 감염 전파 방식이기 때문에, 개인 보호 장구 (personal protective equipment, PPE), 특히 호흡기 보호 장구인 마스크를 적절하게 착용하는 것이 감염 예 방을 위해 매우 중요하다고 할 수 있다. 실제로, 여러 임상 연구를 통해서 병원 환경에서도, 지역사회에서도 마스크를 적절하게 착용하는 것으로 COVID-19의 감염 전파를 효과적으로 차단할 수 있음이 입증되었다. ${ }^{822-25)}$

두번째로 가능한 감염 전파 방식은 바이러스가 묻어 있는 표면의 접촉을 통한 감염 전파 방식이다. SARS$\mathrm{CoV}-2$ 는 침투성 표면(permeable surface)에 비해 플 라스틱이나 금속과 같은 비침투성 표면(impermeable surface)에서 더 오랜 시간 동안 높은 농도로 지속되며 접종 후 3 4일 정도 뒤까지 바이러스가 지속되는 것으 로 알려져 있다. ${ }^{26)}$ 물체의 표면에서 SARS-CoV-2 가 상당한 시간 동안 지속되는 것만으로 물체 표면을 통한 감염전파가 확인되었다고 할 수는 없으나, 집단 발생을 분석한 연구들에서 감염자와의 직접 접촉없이 엘리베이 터나 휴게실, 병실을 공유하는 것만으로 감염전파가 발 생한 사례들이 있음을 고려하면 물체 표면을 통한 감염 전파가 있을 것으로 추론할 수 있다. ${ }^{27)}$ 부적절한 손위생 이 의료종사자의 COVID-19 감염 위험과 연관이 있었 다는 보고나, 물품의 표면소독을 하는 것으로 감염의 위 험을 낮추었다는 보고도 물체 표면을 통한 감염전파 가 능성을 뒷받침한다. ${ }^{13,25)}$ 그러므로, 감염 전파 예방을 위 해서 손위생(hand hygiene)을 철저히 하고, COVID-19 의심환자 또는 확진 환자가 사용한 공간이나 물건에 대 
한 환경 위생(environmental hygiene)도 철저히 해야 하겠다.

COVID-19 수직 감염의 가능성에 대해서도 우려 를 하였으나, 임신부들을 대상으로 한 연구에서 수직감 염에 해당하는 사례의 보고는 지금까지 확인되지 않았 다. ${ }^{28-30)}$ 또한, 모성 사망이나 신생아의 이상 소견도 뚜 렷하지 않았다. 따라서, COVID-19의 수직 감염의 가 능성은 현저히 낮다고 볼 수 있겠다.

\section{임상 양상}

국내 연구에서 COVID-19로 입원한 환자의 나이의 중앙값은 43세로 50세 이상이 $56.7 \%$ 를 차지하였고, 남 자환자의 비율이 $43.6 \%$ 였다. ${ }^{31)}$ 유행 초기 중국에서 발 표된 연구에서 환자의 $81 \%$ 가 경증(mild) 임상 경과를, $14 \%$ 가 중증(severe) 임상 경과를 보이며, $5 \%$ 에서 호흡 부전, 패혈성 쇼크나 다발성 장기부전을 동반한 최중증 (critical) 임상경과를 나타낸다고 보고하였다. ${ }^{32)}$ 경증 환 자는 증상이 경미하고 특별한 치료없이 대부분 회복되기 때문에 임상적으로는 입원 치료가 필요한 경우는 드물다 고 할 수 있고, 중증 또는 최중증 환자의 경우 입원치료 가 필요하다고 할 수 있다. 그러나, 우리나라에서는 가 능한 모든 접촉자를 추적하여 진단하고, 진단된 대부분 의 환자를 격리를 목적으로 입원 치료하였고, 입원 결정 이 환자의 기저질환이나 질환의 중증도와 같은 임상적인 판단에 따라 이뤄진 것이 아니기 때문에, 국내의 자료로 입원이 필요한 환자의 임상 양상을 판단하기는 어려움 이 있다. 따라서 경증환자를 포함한 전반적인 임상 경과 에 대한 이해를 위해 국내 연구 결과를 소개하고, 이어 서 미국이나 유럽의 연구 결과들을 중심으로 임상적 판 단에 따라 입원이 필요한, 중등도 이상의 증증도를 보이 는, 환자들에 대한 임상 양상을 소개하고자 한다.

입원이 필요한 중등증 이상의 중증도를 보이는 COVID-19의 잠복기의 중앙값(사분위수)은 5(2-7)일 이며, $97.5 \%$ 에서 11.5 일 이내에 증상이 발생한다. ${ }^{33,34)}$ 입원하는 환자들은 나이의 중앙값이 47 73세였고, 50 세 이상이 74 86\%를 차지하였으며, 대부분 코호트에 서 남자환자의 비율이 약 60\%로 높게 나타났다(Table 1). ${ }^{33,35-37)}$

경증 환자를 포함한 전체 COVID-19 환자를 대상으
로 하였을 때 약 $25 \%$ 가 기저질환을 동반하고 있고, 입 원환자에서는 60\% 90\%에서 동반한 기저질환이 있었 다. ${ }^{32,35,37,38)}$ 동반된 기저질환 중에는 고혈압(48 57\%)이 가장 흔했고, 당뇨병(17 34\%), 심혈관 질환(21 28\%), 만성 폐질환(4 8\%), 만성 신장 질환(3 13\%), 악성 신 생물(6 8\%) 및 만성 간질환(5\%)을 동반하기도 하였다 (Table 1). ${ }^{36-38)}$

COVID-19의 증상은 무증상부터 심한 폐렴과 호흡 부전 및 장기부전, 사망까지 다양하다. 국내 연구에서 는 가장 흔한 증상은 기침(40.8\%)이었고, 이어서 객담 (25.9\%), 인후통(20.3\%)이었으며, $30 \%$ 미만의 환자가 발열 증상을 경험하였다. ${ }^{31)}$ 반면, 국외 연구들에서는 입 원환자의 가장 흔한 증상 또는 징후는 발열로 입원 환자 들의 90\%까지 발열을 경험하였고, 기침(60 86\%), 호 흡곤란(53 80\%), 피로감(38\%)이 뒤를 이었으며, 소화 기 증상(15 39\%)이나 근육통(15 44\%)을 경험하기도 하였다 (Table 1). ${ }^{33,35-39)}$

Giacomelli A 등 ${ }^{40)}$ 이 COVID-19가 후각 또는 미 각 기능장애(olfactory and/or gustatory dysfunction) 와 연관성이 있음을 보고하였다. 이에 대한 추시연구에 서 COVID-19 환자의 64\% 80\%의 환자가 최소한 후각 또는 미각 기능 이상을 호소하는 것으로 보고하였다. ${ }^{41-}$ 43) 따라서, 상기도 감염 증상과 함께 미각 또는 후각 기 능 이상을 호소하는 경우 COVID-19의 가능성을 고려 해 볼 수 있겠다.

COVID-19는 심장, 뇌, 폐, 간, 신장 및 혈액응고 체 계 등 여러 장기에 합병증을 유발할 수 있다. 심근염, 심근 병증, 심실성 부정맥과 같은 심장 합병증이 비교 적 흔히 보고되었고, ${ }^{44,45}$ 뇌혈관 질환이나 뇌염과 같 은 뇌질환도 합병되는 것으로 보고되었다. ${ }^{41,46)}$ 중증 COVID-19 환자에서는 혈관염이 동반되고, 혈액응고 인자의 활성화가 광범위하게 일어나는 것으로 알려져 있고, ${ }^{47.48)}$ 이로 인한 합병증이 발생할 수 있는데, 입원환 자의 $9.2 \%$ 에서, 중환자실 치료를 받은 환자에서는 $59 \%$ 에서 혈전 색전증을 경험하는 것으로 보고되었다. ${ }^{49}$

전체 환자의 $5 \%$, 입원환자의 17 35\%가 중환자 치료 를 받게 되는데, 대부분 저산소성 호흡부전(hypoxemic respiratory failure)이 원인으로, $55 \%$ 의 환자가 고유량 산소치료가 필요하였고, $26 \%$ 의 환자가 비침습성 또는 
Table 1. COVID-19 입원 환자들의 임상양상 관련 주요 연구의 비교

\begin{tabular}{|c|c|c|c|c|c|}
\hline & Sung HK et al. ${ }^{31)}$ & Guan WJ et al. ${ }^{33)}$ & Garg S. et al. ${ }^{36)}$ & $\begin{array}{c}\text { Richardson S et } \\
\text { al. }^{37)}\end{array}$ & $\begin{array}{c}\text { Docherty AB et } \\
\text { al. }^{35)}\end{array}$ \\
\hline 대상 국가 & 대한민국 & 중국 & 미국 & 미국 (뉴욕) & 영국 \\
\hline 대상 환자수 & 3,060명 & 1,099명 & 1,482 (178)명 & 5,700 명 & 20,133명 \\
\hline 나이 (중앙값, 사분위수) & 43세 (26 57) & 47세 (35 58) & $>50$ 세, $74.5 \%$ & $63(52 \sim 75)$ & $72.9(58.0 \sim 82.0)$ \\
\hline 성별 (남성) & $43.6 \%$ & $58.1 \%$ & $54.4 \%$ & $60.3 \%$ & $59.9 \%$ \\
\hline \multicolumn{6}{|l|}{ 주요 임상증상 } \\
\hline 발열 & $28.8 \%$ & $43.8 \%$ & $85 \%$ & - & $71.6 \%$ \\
\hline 기침 & $40.8 \%$ & $67.8 \%$ & $86.1 \%$ & - & $68.9 \%$ \\
\hline 객담 & $25.9 \%$ & $33.7 \%$ & & - & - \\
\hline 호흡곤란 & $7.4 \%$ & $18.7 \%$ & $80.0 \%$ & - & $71.2 \%$ \\
\hline 인후통 & $20.3 \%$ & $13.9 \%$ & $17.8 \%$ & - & \\
\hline 근육통 & $19.5 \%$ & $14.9 \%$ & $34.4 \%$ & - & \\
\hline \multicolumn{6}{|l|}{ 주요 동반질환 } \\
\hline 당뇨병 & $8.4 \%$ & $7.4 \%$ & $28.3 \%$ & $33.8 \%$ & $28.1 \%$ \\
\hline 고혈압 & $15.8 \%$ & $15.0 \%$ & $49.7 \%$ & $56.6 \%$ & - \\
\hline 만성심장질환 & $2.3 \%$ & $2.5 \%^{*}$ & $14.2 \%$ & $11.1 \%$ & $30.9 \%$ \\
\hline 만성호흡기 질환 & $0.9 \%$ & $1.1 \%$ & $10.7 \%$ & $5.4 \%$ & $17.7 \%$ \\
\hline 악성종양 & $1.6 \%$ & $0.9 \%$ & - & $6 \%$ & $10 \%$ \\
\hline 중환자실 치료 & $1.7 \%$ & $5.0 \%$ & - & $14.2 \%$ & $17 \%$ \\
\hline 사망률 (대상환자) & $1.1 \%$ & $1.4 \%$ & - & $21 \%$ & $26 \%$ \\
\hline
\end{tabular}

*관상 동맥 질환만 반영됨.

침습성 기계환기 치료가 필요하였다. ${ }^{35)}$

입원한 COVID-19 환자의 약 60\%에서 혈청 C-reactive protein(CRP)의 증가나 Lactate dehydrogenase 의 증가가 관찰되고, 약 $1 / 3 \sim 1 / 4$ 의 환자에서 alanine aminotransferase 또는 aspartate aminotransferase의 증가가 관찰된다. ${ }^{50)}$ 림프구 감소나 경도의 혈소판 감소, D-dimer의 증가도 동반되는데, 이러한 검사 이상 소견 은 다른 바이러스 감염이나 폐렴에서도 나타나는 소견 이며, 진단의 특이도가 있는 검사 이상 소견은 없었다.

특징적인 영상 검사 소견은 흥부 단층촬영 영상에 서 미만성, 주변부 간유리 음영(diffuse, peripheral ground-glass opacity)이다. ${ }^{51)}$ 촬영된 시기에 따라 간 질 침윤 양상, 망상형(reticular) 병변 또는 경화(consolidation) 병변이 보이기도 한다. ${ }^{51)}$ 그러나 이러한 흥 부 단층촬영 영상 소견은 다른 감염질환에서도 보일 수 있는 병변이기 때문에 COVID-19의 특이적인 소견이 라고 볼 수는 없다. 또한, 초기 COVID-19 환자에서는
단순 흥부 촬영에서는 $40 \%$ 가 정상 소견이며, 흉부 단 층촬영검사를 하더라도 $15 \%$ 는 정상 소견을 보이는 것 으로 확인되었다. ${ }^{33)}$ 따라서, 영상 검사 소견으로 초기에 COVID-19 환자를 진단하는 데는 제한점이 있다.

\section{치료}

지금까지 여러가지 치료법이나 치료제가 COVID-19 에 치료효과가 있을 것으로 주목을 받았다(Table 2). COVID-19의 치료는 크게 두 가지 방향에서 이뤄지 고 있는데, 첫번째는 지지 치료 특히 호흡기 지지 치 료 (Respiratory supportive care)이다. 현재까지는 임 상 경과를 현저하게 개선할 수 있는 효과적인 항바이러 스제가 없고 중증환자들의 대부분이 저산소성 호흡부전 으로 중환자실 치료를 받게 되므로, 호흡기 지지 치료 가 무엇보다 중요하다고 할 수 있다. ${ }^{35)}$ 비강 캐뉼라 등 을 이용한 기존 산소 요법에도 저산소증이 지속되는 경 우, 인공 호흡기 치료를 하기 전에 고유량 비강 캐뉼라 
Table 2. COVID-19 치료법 또는 치료제 현황하)

\begin{tabular}{|c|c|}
\hline 현재 널리 사용 중 (Widely used) & 인공호흡기와 호흡보조 장치 (ventilators and other respiratory support devices) \\
\hline $\begin{array}{l}\text { 임상시험을 통해 치료 효과 입증 } \\
\text { (Promising evidence) }\end{array}$ & Remdesivir, Corticosteroids (Dexamethasone) \\
\hline $\begin{array}{l}\text { 임상시험 중이거나 치료효과확인 필요 } \\
\text { (Tentative or mixed evidence) }\end{array}$ & $\begin{array}{l}\text { Favipiravir, Molnupiravir, Recombinant ACE-2, Ivermectin, Oleandrin, } \\
\text { 회복기 혈장, Monoclonal antibodies (Bamlanivimab, REGN-COV2), } \\
\text { Interferons, Cytokine Inhibitors, Anticoagulants, 줄기 세포, Vitamin/mineral } \\
\text { 보충제 }\end{array}$ \\
\hline $\begin{array}{l}\text { 임상시험에서 유효성 없음 확인 } \\
\text { (Not promising evidence) }\end{array}$ & Lopinavir/ritonavir, Hydroxychloroquine/chloroquine \\
\hline
\end{tabular}

(heated high-flow nasal canula) 산소 치료를 시도해 볼 수 있다. ${ }^{52)}$ 이러한 치료에도 불구하고 저산소성 호 흡부전이 지속되는 경우 인공호흡기 치료가 필요하고, 인공 호흡기 치료를 해야 하는 경우라면 폐 보호 환기 (lung-protective ventilation)가 추천된다. ${ }^{52)}$

두번째는, 환자에게 투여하는 치료약제로, SARSCoV-2 바이러스 자체를 표적으로 하는 항바이러스 약 물이나 바이러스에 대항하는 면역을 조절하여 병증을 완화시키는 약제들을 사용해 볼 수 있다. COVID-19 의 대유행이 시작된 이후 20 여개 이상의 약제들이 COVID-19의 치료제로 검토 또는 개발되었으나, 지금 까지는 COVID-19를 완치시킬 수 있는 효과적인 약제 는 없다. ${ }^{53)}$

COVID-19 유행 초기에 체외 연구(in vitro study) 에서 항바이러스 효과를 보인 chloroquine/hydroxychloroquine이 치료제로 주목을 받았다. 그러나, chloroquine/hydroxychloroquine은 대규모 임상 연구에서 $\mathrm{SARS}-\mathrm{CoV}-2$ 의 역가를 줄이는 효과가 뚜렷하지 않았 고, 기도 삽관의 위험을 줄이거나 사망률을 줄이는데 있 어서도 유의한 효과를 보이지 않았다. ${ }^{54-56)}$

에이즈 치료제인 Lopinavir/ritonavir 역시 유행 초 기 COVID-19 치료제로 주목을 받았으나, 임상 연구 에서 중증 환자에서 사망률을 감소시키는 효과를 보이 지 않았고, 입원환자 대상 연구에서도 질병의 경과를 개 선시키거나 사망률을 감소시키는 효과는 확인되지 않았 다. ${ }^{57,58)}$

지금까지 임상 시험을 통해 COVID-19에 대한 치료 효과가 어느 정도 입증된 약제는 항바이러스제인 remdesivir와 면역 조절제라고 할 수 있는 corticosteroid이 다. Remdesivir는 바이러스 RNA 합성에 중요한 역할
을 하는 효소인 RNA-dependent RNA polymerase를 억제하는 약제로, 원래는 에볼라 병의 치료제로 개발된 약제다. ${ }^{59)}$ 체외 연구에서 remdesivir가 SARS-CoV-2 를 억제하는 효과가 있음이 확인되었고, ${ }^{60)} 1,063$ 명의 하기도 감염을 동반한 COVID-19 입원환자를 대상으로 한 이중 맹검, 무작위, 위약 대조 임상 시험에서 remdesivir가 위약에 비해 5일 정도 회복기간을 줄여 주는 것으로 확인되었다. ${ }^{61)}$ 현재로서는 remdesivir가 치료 효 과가 확인된 유일한 항바이러스제이지만, 한계점도 분 명한 약제라고 할 수 있다. 정맥 주사로만 투여할 수 있 는 고가의 약제이지만 중환자에서 사망률을 개선시키는 효과 또한 뚜렷하지 않다는 점이다. ${ }^{61,62)}$ 따라서, 투여 대 상환자의 선정이나 투여 시점을 신중하게 결정해야 하 는 약제라고 할 수 있겠다.

COVID-19의 폐렴 악화와 저산소성 호흡 부전이 숙 주 면역반응, 특히 $\mathrm{T}$ 림프구의 과활성화(overactivation)로 인한 폐조직의 면역학적 손상이 주된 원인이라 는 것이 COVID-19 환자의 병리 조직 연구를 통해 밝 혀지면서 면역조절제에 해당하는 corticosteroid가 중증 COVID-19 환자의 치료제로 주목받았다. ${ }^{63)}$ Cortico- $^{-}$ steroid인 dexamethasone의 임상적 유용성은 영국에서 수행된 대규모 임상 시험인 'RECVERY trial'을 통해서 사망률을 개선하는 효과가 확인되었으며, 증상 발생후 7 일 이상 경과한 환자, 인공 호흡기 치료를 받을 정도로 중증 경과를 보이는 환자에서 그 효과가 현저하였다. ${ }^{64)}$

마지막으로 현재 임상 시험이 진행 중인 약제들 중 에서는 SARS-CoV-2에 대한 단일 클론 항체 제제인 Bamlanivimab과 REGN-COV2가 주목을 받고 있다. 또한, 항바이러스제인 molnupiravir도가 2/3상 임상 시 험을 앞두고 있다. 특히 molnupiravir는 경구 투여를 하 
는 약제로 정맥 투여를 해야 하는 기존 약제들에 비해 투여 방법이 간단하다. ${ }^{53)}$ 유병기간을 일부 줄이거나, 사 망률을 다소 낮춰주는 약제들이 있기는 하나, 아직까지 효과적으로 COVID-19를 제어할 수 있는 치료제가 없 는 만큼 향후 이들 약제의 임상 시험 결과를 주목해야 하겠다.

\section{결 론}

2020년 1월에 시작된 COVID-19의 유행은 지금까지 지속되고 있으며, 국내에서도 여러 지역에서 환자가 발 생하고 있고, 감염 경로 불명환자의 비율도 증가하고 있 다. 효과적인 치료제나 백신 개발이 이뤄질 때까지, 상 당한 기간 동안 COVID-19의 유행이 지속될 것으로 예 측되고 있다.

COVID-19은 증상 발생에 선행하여 바이러스가 배 출되어 타인에 감염 전파가 가능하고, 감염 초기에 다른 호흡기 감염과 구별할 수 있는 임상적 특징이 없다. 따 라서, 임상의는 언제 어디서든 감염자를 마주 할 수 있 음을 유념해야 한다. 현재 진행되고 있는 약제나 백신의 임상 시험 결과를 주목하면서 효과적인 치료제나 백신 을 사용할 수 있을 때까지는 의료 현장에서도, 지역사회 에서도 마스크와 같은 개인 보호장구를 적절하게 사용 하고, 손 위생이나 환경 관리 등 감염관리 활동 철저히 해야 하겠다.

중심 단어 : 코로나-19, 사스 코로나 바이러스 2, 코로 나 바이러스, 감염전파, 치료제.

본 연구는 2020년도 부산대학교병원 임상연구비 지원으로 이루 어졌음.

\section{REFERENCES}

1) Lu H, Stratton CW, Tang YW. Outbreak of pneumonia of unknown etiology in Wuhan, China: the mystery and the miracle. J Med Virol 2020;92(4):401-2.

2) World Health Organization. Timeline: WHO's COVID-19 response. 2020 [updated 2020; cited 2020 10-29]; Available from: https://www.who.int/emergencies/diseases/novel-coronavirus-2019/interactive-timeline.

3) World Health Organization. WHO Coronavirus Disease
(COVID-19) Dashboard. 2020 [updated 2020; cited 2020 1029]; Available from: https://covid19.who.int/.

4) 질병관리청. 코로나바이러스감염증-19 (COVID-19). 2020 [updated 2020; cited 2020 10-29]; Available from: http:// ncov.mohw.go.kr/.

5) Chan JF, Yuan S, Kok KH, To KK, Chu H, Yang J, et al. A familial cluster of pneumonia associated with the 2019 novel coronavirus indicating person-to-person transmission: a study of a family cluster. Lancet (London, England) 2020; 395(10223):514-23.

6) Ren LL, Wang YM, Wu ZQ, Xiang ZC, Guo L, Xu T, et al. Identification of a novel coronavirus causing severe pneumonia in human: a descriptive study. Chin Med J 2020; 133(9):1015-24.

7) Gorbalenya AE, Baker SC, Baric RS, de Groot RJ, Drosten $\mathrm{C}$, Gulyaeva AA, et al. The species severe acute respiratory syndrome-related coronavirus: classifying 2019-nCoV and naming it SARS-CoV-2. Nat Microbiol 2020;5(4):536-44.

8) Chu DK, Akl EA, Duda S, Solo K, Yaacoub S, Schünemann HJ. Physical distancing, face masks, and eye protection to prevent person-to-person transmission of SARS-CoV-2 and COVID-19: a systematic review and meta-analysis. Lancet (London, England) 2020;395(10242):1973-87.

9) He X, Lau EHY, Wu P, Deng X, Wang J, Hao X, et al. Temporal dynamics in viral shedding and transmissibility of COVID-19. Nat Med 2020;26(5):672-5.

10) Wölfel R, Corman VM, Guggemos W, Seilmaier M, Zange S, Müller MA, et al. Virological assessment of hospitalized patients with COVID-2019. Nature 2020;581(7809):465-9.

11) Ganyani T, Kremer C, Chen D, Torneri A, Faes C, Wallinga $\mathrm{J}$, et al. Estimating the generation interval for coronavirus disease (COVID-19) based on symptom onset data, March 2020. Euro surveillance: bulletin Europeen sur les maladies transmissibles $=$ European Communicable Disease Bulletin 2020;25(17).

12) Sun J, Xiao J, Sun R, Tang X, Liang C, Lin H, et al. Prolonged persistence of SARS-CoV-2 RNA in body fluids. Emerg Infect Dis 2020;26(8):1834-8.

13) Cheng HY, Jian SW, Liu DP, Ng TC, Huang WT, Lin HH. Contact tracing assessment of COVID-19 transmission dynamics in Taiwan and risk at different exposure periods before and after symptom onset. J JAMA Intern Med 2020;180 (9):1156-63.

14) World Health Organization. Clinical management of COVID-19. Genova: World Health Organization; 2020 [updated 2020; cited 2020]; Available from.

15) van der Vries E, Stittelaar KJ, van Amerongen G, Veldhuis Kroeze EJ, de Waal L, Fraaij PL, et al. Prolonged influenza virus shedding and emergence of antiviral resistance in immunocompromised patients and ferrets. PLoS Pathog 2013; 9(5):e1003343.

16) Bansal A, Kumar A. Re: Lan Zhu, Nianqiao Gong, Bin Liu, et al. Coronavirus disease 2019 Pneumonia in immunosuppressed renal transplant recipients: a summary of 10 confirmed cases in Wuhan, China. Eur Urol 2020;77:748-54. Eur Urol 2020;78(4):e158. 
17) Lee YL, Liao CH, Liu PY, Cheng CY, Chung MY, Liu CE, et al. Dynamics of anti-SARS-Cov-2 IgM and IgG antibodies among COVID-19 patients. J Infect 2020;81(2):e55-8.

18) van Kampen JJA, van de Vijver DAMC, Fraaij PLA, Haagmans B, Lamers M, Okba N, et al. Shedding of infectious virus in hospitalized patients with coronavirus disease-2019 (COVID-19): duration and key determinants. medRxiv;2020.

19) 질병관리청. 코로나바이러스감염증-19 대응 지침(의료기 관용) 제1-1판. 2020 [updated 2020; cited]; Available from.

20) Guo ZD, Wang ZY, Zhang SF, Li X, Li L, Li C, et al. Aerosol and surface distribution of severe acute respiratory syndrome coronavirus 2 in hospital wards, Wuhan, China, 2020. Emerg Infect Dis 2020;26(7):1583-91.

21) Lednicky JA, Lauzardo M, Fan ZH, Jutla A, Tilly TB, Gangwar M, et al. Viable SARS-CoV-2 in the air of a hospital room with COVID-19 patients. Int J Infect Dis 2020;100: 476-82.

22) Chou R, Dana T, Jungbauer R, Weeks C, McDonagh MS. Masks for prevention of respiratory virus infections, Including SARS-CoV-2, in health care and community settings: a living rapid review. Ann Intern Med 2020;173(7):542-55.

23) Lee JK, Jeong HW. Wearing face masks regardless of symptoms is crucial for preventing the spread of COVID-19 in hospitals. Infect Control Hosp Epidemiol 2020:1-2.

24) Lyu W, Wehby GL. Community use of face masks and COVID-19: evidence from a natural experiment of state mandates In the US. Health Aff (Millwood) 2020;39(8):1419-25.

25) Wang Y, Tian H, Zhang L, Zhang M, Guo D, Wu W, et al. Reduction of secondary transmission of SARS-CoV-2 in households by face mask use, disinfection and social distancing: a cohort study in Beijing, China. BMJ Glob Health 2020;5(5):e002794.

26) van Doremalen N, Bushmaker T, Morris DH, Holbrook MG, Gamble A, Williamson BN, et al. Aerosol and surface stability of SARS-CoV-2 as compared with SARS-CoV-1. N Engl J Med 2020;382(16):1564-7.

27) Cai J, Sun W, Huang J, Gamber M, Wu J, He G. Indirect virus transmission in cluster of COVID-19 cases, Wenzhou, China, 2020. Emerg Infect Dis 2020;26(6):1343-5.

28) Chen H, Guo J, Wang C, Luo F, Yu X, Zhang W, et al. Clinical characteristics and intrauterine vertical transmission potential of COVID-19 infection in nine pregnant women: a retrospective review of medical records. Lancet 2020;395(10226):809-15.

29) Dashraath P, Wong JLJ, Lim MXK, Lim LM, Li S, Biswas A, et al. Coronavirus disease 2019 (COVID-19) pandemic and pregnancy. Am J Obstet Gynecol 2020;222(6):521-31.

30) Zeng L, Xia S, Yuan W, Yan K, Xiao F, Shao J, et al. Neonatal early-onset infection with SARS-CoV-2 in 33 neonates born to mothers with COVID-19 in Wuhan, China. JAMA Pediatr 2020;174(7):722-5.

31) Sung HK, Kim JY, Heo J, Seo H, Jang YS, Kim H, et al. Clinical course and outcomes of 3,060 patients with coronavirus disease 2019 in Korea, January-May 2020. J Korean Med Sci 2020;35(30):e280.

32) The novel coronavirus pneumonia emergency response ep- idemiology team. The epidemiological characteristics of an outbreak of 2019 novel coronavirus diseases (COVID-19) China, 2020. China CDC Weekly 2020;2:1-10.

33) Guan WJ, Ni ZY, Hu Y, Liang WH, Ou CQ, He JX, et al. Clinical characteristics of coronavirus disease 2019 in China. N Engl J Med 2020;382(18):1708-20.

34) Lauer SA, Grantz KH, Bi Q, Jones FK, Zheng Q, Meredith $\mathrm{HR}$, et al. The incubation period of coronavirus disease 2019 (COVID-19) from publicly reported confirmed cases: estimation and application. Ann Intern Med 2020;172(9):57782.

35) Docherty AB, Harrison EM, Green CA, Hardwick HE, Pius R, Norman L, et al. Features of 20133 UK patients in hospital with covid-19 using the ISARIC WHO clinical characterisation protocol: prospective observational cohort study. BMJ 2020;369:m1985.

36) Garg S, Kim L, Whitaker M, O'Halloran A, Cummings C, Holstein R, et al. Hospitalization rates and characteristics of patients hospitalized with laboratory-confirmed coronavirus disease 2019 - COVID-NET, 14 States, march 1-30, 2020. MMWR Morb Mortal Wkly Rep 2020;69(15):458-64.

37) Richardson S, Hirsch JS, Narasimhan M, Crawford JM, McGinn T, Davidson KW, et al. Presenting characteristics, comorbidities, and outcomes among 5,700 patients hospitalized with COVID-19 in the New York city area. JAMA 2020;323(20):2052-9.

38) Grasselli G, Zangrillo A, Zanella A, Antonelli M, Cabrini L, Castelli A, et al. Baseline characteristics and outcomes of 1591 patients infected with SARS-CoV-2 admitted to ICUs of the Lombardy region, Italy. JAMA 2020;323(16):1574-81.

39) Huang C, Wang Y, Li X, Ren L, Zhao J, Hu Y, et al. Clinical features of patients infected with 2019 novel coronavirus in Wuhan, China. Lancet 2020;395(10223):497-506.

40) Giacomelli A, Pezzati L, Conti F, Bernacchia D, Siano M, Oreni L, et al. Self-reported olfactory and taste disorders in patients with severe acute respiratory coronavirus 2 infection: a cross-sectional study. Clin Infect Dis 2020;71(15):889-90.

41) Helms J, Kremer S, Merdji H, Clere-Jehl R, Schenck M, Kummerlen C, et al. Neurologic features in severe SARSCoV-2 infection. N Engl J Med 2020;382(23):2268-70.

42) Lechien JR, Chiesa-Estomba CM, De Siati DR, Horoi M, Le Bon SD, Rodriguez A, et al. Olfactory and gustatory dysfunctions as a clinical presentation of mild-to-moderate forms of the coronavirus disease (COVID-19): a multicenter European study. E Eur Arch Otorhinolaryngol 2020;277(8):2251-61.

43) Spinato G, Fabbris C, Polesel J, Cazzador D, Borsetto D, Hopkins $\mathrm{C}$, et al. Alterations in smell or taste in mildly symptomatic outpatients with SARS-CoV-2 infection. JAMA 2020;323(20):2089-90.

44) Butt N, Arshid A, Ahmad SA, Khalid N, Kayani WT. Cardiovascular complications in COVID-19. Am J Emerg Med 2020;S0735-6757(20)30624-0.

45) Hendren NS, Drazner MH, Bozkurt B, Cooper LT. Description and proposed management of the acute COVID-19 cardiovascular syndrome. Circulation 2020;141(23):1903-14.

46) Mao L, Jin H, Wang M, Hu Y, Chen S, He Q, et al. Neuro- 
logic manifestations of hospitalized patients with coronavirus disease 2019 in Wuhan, China. JAMA Neurol 2020;77(6): 683-90.

47) Ackermann M, Verleden SE, Kuehnel M, Haverich A, Welte $\mathrm{T}$, Laenger $\mathrm{F}$, et al. Pulmonary vascular endothelialitis, thrombosis, and angiogenesis in Covid-19. N Engl J Med 2020;383 (2):120-8.

48) Tang N, Li D, Wang X, Sun Z. Abnormal coagulation parameters are associated with poor prognosis in patients with novel coronavirus pneumonia. J Thromb Haemost 2020;18(4): 844-7.

49) Middeldorp S, Coppens M, van Haaps TF, Foppen M, Vlaar AP, Müller MCA, et al. Incidence of venous thromboembolism in hospitalized patients with COVID-19. J Thromb Haemost 2020;18(8):1995-2002.

50) Rodriguez-Morales AJ, Cardona-Ospina JA, Gutiérrez-Ocampo E, Villamizar-Peña R, Holguin-Rivera Y, Escalera-Antezana JP, et al. Clinical, laboratory and imaging features of COVID-19: a systematic review and meta-analysis. Travel Med Infect Dis 2020;34:101623.

51) Shi H, Han X, Jiang N, Cao Y, Alwalid O, Gu J, et al. Radiological findings from 81 patients with COVID-19 pneumonia in Wuhan, China: a descriptive study. The Lancet Infectious diseases 2020;20(4):425-34.

52) Alhazzani W, Møller MH, Arabi YM, Loeb M, Gong MN, Fan E, et al. Surviving sepsis campaign: guidelines on the management of critically ill adults with coronavirus disease 2019 (COVID-19). Intensive Care Med 2020;46(5):854-87.

53) Corum J, Wu KJ, Zimmer C. Coronavirus Drug and Treatment Tracker. The New York Times; 2020 [updated 2020 October 23, 2020; cited 2020 10-27]; Available from: https:// www.nytimes.com/interactive/2020/science/coronavirus-drugs-treatments.html

54) Geleris J, Sun Y, Platt J, Zucker J, Baldwin M, Hripcsak G, et al. Observational study of hydroxychloroquine in hospitalized patients with Covid-19. N Engl J Med 2020;382(25):2411-8.

55) Rosenberg ES, Dufort EM, Udo T, Wilberschied LA, Kumar J, Tesoriero J, et al. Association of treatment With hydroxychloroquine or azithromycin with in-hospital mor- tality in patients with COVID-19 in New York State. JAMA 2020;323(24):2493-502.

56) Tang W, Cao Z, Han M, Wang Z, Chen J, Sun W, et al. Hydroxychloroquine in patients with mainly mild to moderate coronavirus disease 2019: open label, randomised controlled trial. BMJ 2020;369:m1849.

57) Cao B, Wang Y, Wen D, Liu W, Wang J, Fan G, et al. A trial of lopinavir-ritonavir in adults hospitalized with severe Covid-19. N Engl J Med 2020;382(19):1787-99.

58) RECOVERY Collaborative Group. Lopinavir-ritonavir in patients admitted to hospital with COVID-19 (RECOVERY): a randomised, controlled, open-label, platform trial. Lancet 2020;396(10259):1345-52.

59) Mulangu S, Dodd LE, Davey RT, Tshiani Mbaya O, Proschan $\mathrm{M}$, Mukadi D, et al. A randomized, controlled trial of ebola virus disease therapeutics. N Engl J Med 2019;381(24):2293303.

60) Wang M, Cao R, Zhang L, Yang X, Liu J, Xu M, et al. Remdesivir and chloroquine effectively inhibit the recently emerged novel coronavirus (2019-nCoV) in vitro. Cell Res 2020;30(3):269-71.

61) Beigel JH, Tomashek KM, Dodd LE, Mehta AK, Zingman BS, Kalil AC, et al. Remdesivir for the Treatment of Covid-19 - Final Report. N Engl J Med 2020;383(19):181326.

62) Spinner CD, Gottlieb RL, Criner GJ, Arribas López JR, Cattelan AM, Soriano Viladomiu A, et al. Effect of remdesivir vs standard care on clinical status at 11 days in patients with moderate COVID-19: a randomized clinical trial. JAMA 2020;324(11):1048-57.

63) Xu Z, Shi L, Wang Y, Zhang J, Huang L, Zhang C, et al. Pathological findings of COVID-19 associated with acute respiratory distress syndrome. Lancet Respir Med 2020;8(4): 420-2.

64) Horby P, Lim WS, Emberson JR, Mafham M, Bell JL, Linsell L, et al. Dexamethasone in hospitalized patients with Covid-19 - preliminary eport. N Engl J Med 2020; NEJMoa2021436. 